\title{
IaAtat:
}

\section{材料機能の電気化学 $\mathrm{IV}$}

\section{- 一次電池, 二次電池, 燃料電池の電気化学-}

\section{杉 本 克 久*}

\section{$4 \cdot 1$ 本章 $の$ 目的}

第 1 章では, 電気化学反応の平衡電位々電池の起電力に ついて学んだ. 第 2 章では電気化学反応の速度を支配する 因子について学んだ。そして, 第 3 章ではアノード, カソ 一ド両反応が同一電極上で同時に生じる金属の腐食現象を例 にとって複合電極反応の電位と反応速度について学んだ．本 章ではアノード，カソード各反応が別々の電極上で行われる 化学電池について, 種類別に電池反応と電極材料に関して学 ぶ. 化学電池は一次電池, 二次電池, 燃料電池に分類され, いずれについても古くから様々な種類の電池が実用されてい る.ここでは, 化学電池に共通的な構造と性能評価法につい て述べたあと実用電池の中の代表的一次電池, 二次電池, 燃 料電池について動作原理と材料を解説する. そしてさらに， 最近進歩の著しい高性能化学電池に用いられている新しい技 術についても触れる。 なお，本章の多くの部分は著者が執筆 した本会刊金属化学入門シリーズ 4 材料電子化学 ${ }^{(1)}$ に基づ いている。一層詳しい内容については，そちらを参照される ことを希望する。

\section{$4 \cdot 2$ 化学電池の構造}

\section{$4 \cdot 2 \cdot 1$ 一次電池および二次電池の構造}

放電のみできて充電が不可能な電池を一次電池 (primary cell), 放電抢よび充電が共に可能な電池を二次電池 (secondary cell）という. しかし，電池の基本的構造は両者とも同 じである. 一次電池と二次電池の基本構造を図4・1亿示す. 一次電池では正極 (positive electrode)あるいは負極 (negative electrode) の電気化学反応に可逆性の悪い反応を利用し ているのに対して, 二次電池では正極, 負極共に可逆性の良 い電気化学反応を利用している.

電池の起電力を生ずる電気化学反応に関わる物質を活物質 (active material) という. 正極での反応に関わる物質が正極 活物質, 負極での反応に関わる物質が負極活物質である. 活

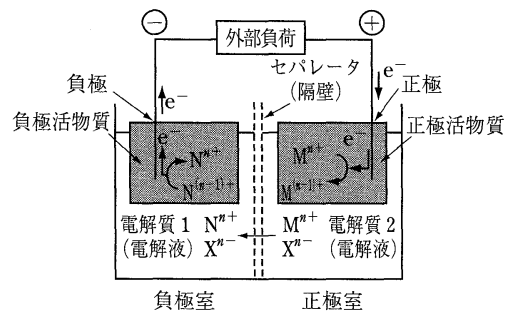

図 $4 \cdot 1$ 一次電池々二次電池の基本構造.

物質は電解液中に入れられることもある. 正極室, 負極室の 電解質が混じり合わないように, 両室間にはイオン交換の及 を行うセパレータ(separator, 隔壁)が設けられている.

\section{$4 \cdot 2 \cdot 2$ 燃料電池の構造}

燃料電池 (fuel cell) の基本構造も一次電池抢よび二次電池 の構造とまったく同じである. しかし, 一次電池および二次 電池では正極活物質および負極活物質を電池内部に貯蔵して いるのに対して, 燃料電池ではこれらを電池外部から常時供 給している. また, 多くの一次電池抢よび二次電池では正極 と負極を隔てるセパレータが電池内部にあるのに対して, 燃 料電池ではこれが電池内部にはなく単セル (single cell) 同士 を接続する導電性隔壁(バイポーラ板； bipolar plate，ある いはインタコネクト; interconnect) として電池外部に設け られている。

燃料電池の基本構造を図4・2に示した。電解質には, 液体 電解質と固体電解質が用いられる. 負極活物質となる燃料は 多くの場合水素ガス $\left(\mathrm{H}_{2}\right)$ であり，また，正極活物質となる 酸化剂は多くの場合酸素ガス $\left(\mathrm{O}_{2}\right)$ である. 燃料ガスの酸化 反応が電池反応となる. 負極および正極には, 多孔質のガス 拡散電極が用いられる. 反応を促進するため, 正負両電極の 表面には触媒が付けられている，セパレータはガスの流路を 形成すると同時に単電池同士を連結するための接続子(イン タコネクト)になっている.なお，負極は燃料極 (fuel electrode)，正極は空気極 (air electrode； $\mathrm{O}_{2}$ を空気から取ると

\footnotetext{
* 東北大学名誉教授

Electrochemistry of Material Functions, Chapter 4 Electrochemistry of Primary, Secondary and Fuel Cells; Katsuhisa Sugimoto (Professor Emeritus, Tohoku University, Sendai)

Keywords: primary cells, secondary cells, fuel cells, electromotive force, cell reactions, polarization curves, discharge curves, cell materials 2006年10月10日受理
} 


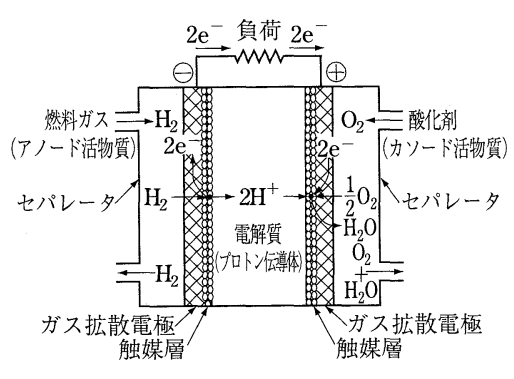

図 $4 \cdot 2$ 燃料電池の基本 構造.

き）と呼ばれることもある.

然料電池は放電しかできないことでは一次電池と同じであ るが，負極活物質および正極活物質を外部から供給し続ける 限り放電を継続できるので，一種の発電機と考えることがで きる。

\section{3 化学電池の種類}

\section{$4 \cdot 3 \cdot 1$ 一次電池の種類}

代表的な実用一次電池とその特性を表4・1に示す(2)-(5). 一 次電池は放電の及行い充電については考えないので，二次電 池に比べて正極および負極活物質の種類, 電池の形状, サイ ズなどの選択に制約が少ない. 同一寸法の一次電池と二次電 池を比較すると，一次電池の方がエネルギ一密度は大きい. 一次電池は使用されるまで長期間保存されることが多いの で，自己放電が少ないことが要求される.

一次電池の中で最も多く使用されているのはマンガン乾電 池である.この電池は放電時の電圧低下が早いなどの欠点は あるが, 安価でかつ信頼性が高い.マンガン乾電池の電解質
をアルカリ水溶液に変えたのが, アルカリマンガン乾電池で ある. マンガン乾電池よりも容量が大きくかつ大きな出力が 得られる. 表 $4 \cdot 1$ には記載されていないが, 近年, アルカリ マンガン乾電池の改良型としてオキシライド乾電池 ( Oxy Nickel Hydroxide から採られた名称) と呼ばれる新しい電池 が市販されている.これはアルカリマンガン乾電池の正極活 物質に二酸化マンガン $\left(\mathrm{MnO}_{2}\right)$ と共にオキシ水酸化ニッケル $(\mathrm{NiOOH})$ を使用したものである.この電池の出力および容 量は, アルカリマンガン乾電池の1.5倍と言われている. 負 極に金属リチウムを用い，電解液に非水電解液を用いるリチ ウム電池は $3 \mathrm{~V}$ 以上の高電圧が得られ, 高エネルギー密度 でかつ自己放電も少ないので, カメラなどの精密電子機器に 用いられている. 酸化銀電池は, 出力電圧が極めて平坦なこ とが特徵である.一次電池には，残存容量が表示できること が望まれているが，これの実現はなかなか容易ではない.

\section{$4 \cdot 3 \cdot 2$ 二次電池の種類}

代表的な実用二次電池を表4-2に示す ${ }^{(2)-(5)}$. 二次電池は放 電および充電を繰り返し行わねばならないので, 電極活物質 の種類や電池の構造には制約があり, その作製は一次電池よ りは難しい. しかし, 現在では, 容量約 $10000 \mathrm{Ah}$ の大型の ものから約 $0.01 \mathrm{Ah}$ の小形のものまで, 種々のタイプのもの が色々の分野で使われている. 従来, 数 $\mathrm{Ah}$ 以上の大型のも のには鉛蓄電池が，また，小形の小容量のものにはニッケ ル・カドミウム蓄電池が用いられてきた. しかし, 最近では 小形軽量で高エネルギー密度の二次電池が求められているこ とと, カドミウムの使用が環境保全上好ましくないことか ら, ニッケル・カドミウム蓄電池の需要が減り, 代わってニ ッケル・水素蓄電池やリチウムイオン二次電池などの新しい

表4.1 代表的な実用一次電池の種類とその特性.

\begin{tabular}{|c|c|c|c|c|}
\hline \multirow{2}{*}{ 名 称 } & \multirow{2}{*}{ 負柍 $\mid$ 電解質|盛極 } & \multirow{2}{*}{$\begin{array}{l}\text { 公称 } \\
\text { 電圧/V }\end{array}$} & \multicolumn{2}{|c|}{ エネルギー密度 } \\
\hline & & & $\mathrm{Wh} / \mathrm{kg}[\mathrm{kJ} / \mathrm{kg}]$ & $\mathrm{MWh} / \mathrm{m}^{3}\left[\mathrm{GJ} / \mathrm{m}^{3}\right]$ \\
\hline マンガン乾電池 & $\mathrm{Zn}\left|\mathrm{ZnCl}_{2}, \mathrm{NH}_{4} \mathrm{Cl}\right| \mathrm{MnO}_{2}$ & 1.5 & $50[180]$ & $200[720]$ \\
\hline アルカリマンガン乾電池 & $\mathrm{Zn}|\mathrm{KOH}| \mathrm{MnO}_{2}$ & 1.5 & $100[360]$ & $320[1152]$ \\
\hline 酸化銀電池 & $\mathrm{Zn}|\mathrm{KOH}| \mathrm{Ag}_{2} \mathrm{O}$ & 1.55 & $100[360]$ & $450[1620]$ \\
\hline 空気亜鉛電池 & $\mathrm{Zn}|\mathrm{KOH}| \mathrm{O}_{2}$ & 1.4 & $100[360]$ & $1200[4320]$ \\
\hline 二酸化マンガンリチウム電池 & $\mathrm{Li}\left|\mathrm{LiClO}_{4}, \mathrm{PC}\right| \mathrm{MnO}_{2}$ & 3 & $300[1080]$ & $400[1440]$ \\
\hline フッ化黒鉛リチウム電池 & $\mathrm{Li}\left|\mathrm{LiBF}_{4}, \mathrm{BL}\right|(\mathrm{CF})_{n}$ & 3 & $300[1080]$ & $400[1440]$ \\
\hline 塩化チオニルリチウム電池 & $\mathrm{Li}\left|\mathrm{LiClO}_{4}, \mathrm{SOCl}_{2}\right| \mathrm{SOCl}_{2}$ & 3.6 & $420[1512]$ & $1000[3600]$ \\
\hline
\end{tabular}

* PC : プロピレンカーボネート, BL : $\gamma$-ブチロラクトン

表 $4 \cdot 2$ 代表的な実用二次電池の種類とその特性.

\begin{tabular}{|c|c|c|c|c|}
\hline \multirow{2}{*}{ 名 称 } & \multirow{2}{*}{ 負構 $\mid$ 電解質|正極 } & \multirow{2}{*}{$\begin{array}{l}\text { 枀称 } \\
\text { 電圧/V }\end{array}$} & \multicolumn{2}{|c|}{ エネルギー密度 } \\
\hline & & & $\mathrm{Wh} / \mathrm{kg}[\mathrm{kJ} / \mathrm{kg}]$ & $\mathrm{MWh} / \mathrm{m}^{3}\left[\mathrm{GJ} / \mathrm{m}^{3}\right]$ \\
\hline 鉛蓄電池 ～～～～～～ & $\mathrm{Pb}\left|\mathrm{H}_{2} \mathrm{SO}_{4}\right| \mathrm{PbO}_{2}$ & 2.0 & $35(170)[126(612)]$ & $84[302.4]$ \\
\hline ニッケル・カドミウム電池 & $\mathrm{Cd}|\mathrm{KOH}| \mathrm{NiOOH}$ & 1.2 & $50(240)[180(864)]$ & $137[493.2]$ \\
\hline ニッケル・水素電池 & $\mathrm{MH}|\mathrm{KOH}| \mathrm{NiOOH}$ & 1.2 & $55(280)[198(553)]$ & $200[720]$ \\
\hline リチウム二次電池 & $\mathrm{Li}-\mathrm{Al}\left|\mathrm{LiBF}_{4}, \mathrm{PC}\right| \mathrm{V}_{2} \mathrm{O}_{3}$ & 3.0 & $55[(158)]$ & $130[468]$ \\
\hline リチウムイオン二次電池 & $\mathrm{Li}_{x} \mathrm{C}_{6}\left|\mathrm{LiClO}_{4}, \mathrm{PC}\right| \mathrm{LiCoO}_{2}$ & 3.0 & $120(415)[432(1494)]$ & $300[1080]$ \\
\hline ニッケル・亜鉛電池 & $\mathrm{Zn}|\mathrm{KOH}| \mathrm{NiOOH}$ & 1.3 & $70(340)[432(1494)]$ & $170[612]$ \\
\hline 亜鉛·塩素電池 & $\mathrm{Zn}\left|\mathrm{ZnCl}_{2}\right| \mathrm{Cl}_{2}$ & 1.9 & $465[1674]$ & \\
\hline レドックスフロー電池 & $\mathrm{Cr}^{2+}|\mathrm{HCl}| \mathrm{Fe}^{3+}$ & 0.9 & $103[370]$ & \\
\hline ナトリウム・硫黄電池 & $\mathrm{Na}\left|\beta-\mathrm{Al}_{2} \mathrm{O}_{3}\right| \mathrm{S}$ & 1.8 & $100(780)[360(2808)]$ & \\
\hline
\end{tabular}

*括弧内は理論エネルギー密度

** $\mathrm{MH}$ : 金属水素化物, $\mathrm{PC}:$ プロピレンカーボネート 
表 $4 \cdot 3$ 代表的な燃料電池とその種類とその特徵.

\begin{tabular}{|c|c|c|c|c|c|}
\hline 種 類 & 燃 料 & 電解質（電荷担体） & 酸化剤 & 作動温度 & 発電効率 \\
\hline アルカリ型(AFC) & $\mathrm{H}_{2}$ & $\mathrm{KOH}$ 水溶液 $\left(\mathrm{OH}^{-}\right)$ & $\mathrm{O}_{2}$ & 室温～513 K & $45 \sim 50 \%$ \\
\hline リン酸型 (PAFC) & $\mathrm{H}_{2}$ & $\mathrm{H}_{3} \mathrm{PO}_{4}$ 水溶液 $\left(\mathrm{H}^{+}\right)$ & 空 気 & $373 \sim 483 \mathrm{~K}$ & $40 \sim 45 \%$ \\
\hline 溶融炭酸塩型 (MCFC) & $\mathrm{H}_{2}, \mathrm{CO}$ & $\mathrm{Li}_{2} \mathrm{CO}_{3}-\mathrm{Na}_{2} \mathrm{CO}_{3}$ 溶融塩 $\left(\mathrm{CO}_{3}^{2-}\right)$ & 空気 $+\mathrm{CO}_{2}$ & $873 \sim 973 \mathrm{~K}$ & $50 \sim 65 \%$ \\
\hline 固体酸化物型 (SOFC) & $\mathrm{H}_{2}, \mathrm{CO}$ & $\mathrm{ZrO}_{2} \cdot \mathrm{Y}_{2} \mathrm{O}_{3}$ セラミックス $\left(\mathrm{O}^{2-}\right)$ & 空 気 & $1173 \sim 1273 \mathrm{~K}$ & $55 \sim 70 \%$ \\
\hline 固体高分子型 (PEFC) & $\mathrm{H}_{2}, \mathrm{CH}_{3} \mathrm{OH}$ & 陽イオン交換膜 $\left(\mathrm{H}^{+}\right)$ & 空 気 & 室温〜373 K & $30 \sim 40 \%$ \\
\hline
\end{tabular}

タイプの高エネルギー密度二次電池に対する需要が増えてい る. また，大気污染の防止の観点から，石油燃料に代わって 電気エネルギーで駆動する自動車の開発が急がれていること も, 大型高エネルギ一密度二次電池の開発を促進している.

\section{$4 \cdot 3 \cdot 3$ 燃料電池の種類}

代表的な燃料電池の種類を表4-3に示した，燃料電池では 電解質は一つの電池に一つの種類しか用いられていないの で, 燃料電池の分類は電解質の種類に基づいて行われてい る. また，作動温度に基づく燃料電池の分類も行われてい る.この場合，作動温度が室温から $373 \mathrm{~K}$ 程度のものを常 温， $573 \mathrm{~K}$ 前後のものを中温， $773 \mathrm{~K}$ 以上のものを高温と称 している．例えば，電解質が固体酸化物で作動温度が $773 \mathrm{~K}$ 以上であれば，高温固体酸化物型燃料電池之呼ぶ.

燃料電池はアルカリ型, リン酸型, 溶融炭酸塩型, 固体酸 化物型, 固体高分子型の五つに分類される. アルカリ型は初 期のものであり，アポロ宇宙船用として使用された。リン酸 型は小規模分散発電用に実用されている．溶融炭酸塩型は中 規模発電プラント用として，また，固体酸化物型は小規模発 電モジュール用および中規模発電プラント用としての開発が 進められている. 固体高分子型は然料電池自動車用として積 極的な開発が行われている. 固体高分子型の一種である直接 メタノール型は携帯電子機器用として開発されている.

\section{$4 \cdot 4$ 電池の起電力}

電池の起電力については，第 1 章 $1 \cdot 12$ において既に述べ た.ここでは，電池についての理解を助けるため，最小限の 復習をしておくことにする.

今, 電池の正極での電気化学反応を式 $(4 \cdot 1)$, この反応の 平衡電位を式 $(4 \cdot 2)$ で表す(6)-(8).

$$
\begin{aligned}
x_{1} \mathrm{Ox}_{1} & +m_{1} \mathrm{H}^{+}+n_{1} \mathrm{e}^{-}=y_{1} \operatorname{Red}_{1}+z_{1} \mathrm{H}_{2} \mathrm{O} \\
E_{1}= & E_{1}^{0}-\left(0.0591 m_{1} / n_{1}\right) \mathrm{pH} \\
& +\left(0.0591 / n_{1}\right) \log \left(a_{\mathrm{Ox}_{1}}^{x_{1}} / a_{\mathrm{Red}_{1}}^{y_{1}}\right)
\end{aligned}
$$

ただし， $E_{1}^{0}$ は式 $(4 \cdot 1)$ の標準電極電位，温度は $298 \mathrm{K，その}$ 他の記号の意味は第 1 章1·15 と同じとする. 同様に，電池 の負極での電気化学反応を式 $(4 \cdot 3)$, この反応の平衡電位を 式(4·4)で表す.

$$
\begin{aligned}
x_{2} \mathrm{Ox}_{2} & +m_{2} \mathrm{H}^{+}+n_{2} \mathrm{e}^{-}=y_{2} \operatorname{Red}_{2}+z_{2} \mathrm{H}_{2} \mathrm{O} \\
E_{2}= & E_{2}^{0}-\left(0.0591 m_{2} / n_{2}\right) \mathrm{pH} \\
& +\left(0.0591 / n_{2}\right) \log \left(a_{\mathrm{Ox}_{2}}^{x_{2}} / a_{\mathrm{Red}_{2}}^{y_{2}}\right)
\end{aligned}
$$

$E_{2}^{0}$ は式 $(4 \cdot 3)$ の標準電極電位である. 式 $(4 \cdot 1)$ は正極である のでこれの平衡電位 $E_{1}$ は負極である式 $(4 \cdot 3)$ の平衡電位 $E_{2}$ よりも高いとする. 式 $(4 \cdot 1)$ と式 $(4 \cdot 3)$ からなる電池の構成
は，第 1 章1·14で述べたように，次のように書くことがで きる。

$\operatorname{Red}_{2}\left|\mathrm{Ox}_{2}, \mathrm{H}^{+}, \mathrm{H}_{2} \mathrm{O}: \mathrm{Ox}_{1}, \mathrm{H}^{+}, \mathrm{H}_{2} \mathrm{O}\right| \operatorname{Red}_{1}$ この電池の起電力 $E_{\mathrm{emf}}$ は次式で表される.

$$
E_{\mathrm{emf}}=E_{1}-E_{2} \fallingdotseq E_{1}^{0}-E_{2}^{0}
$$

\section{$4 \cdot 5$ 電池のエネルギー変換効率}

式 $(4 \cdot 1)$ と式 $(4 \cdot 3)$ からなる電池について考える.これら の反応の Gibbs 自由エネルギー变化をそれぞれ $\Delta G_{1}$ および $\Delta G_{2}$ とすると, これらのエネルギー変化がすべて電気エネ ルギーに変換されたときには，次のように表すことができる.

$$
\begin{aligned}
& -\Delta G_{1}=n_{1} F E_{1} \\
& -\Delta G_{2}=n_{2} F E_{2}
\end{aligned}
$$

$E_{1}, E_{2}$ は, 各反応に伴う電圧変化である. 式 $(4 \cdot 1)$ と式 (4·3) が組み合わされて電池が構成されたときには，[式(4. 1) $\times n_{2}-$ 式 $\left.(4 \cdot 3) \times n_{1}\right]$ が電池反応式となる.

$$
n_{2} x_{1} \mathrm{Ox}_{1}+n_{1} y_{2} \operatorname{Red}_{2}=n_{2} y_{1} \operatorname{Red}_{1}+n_{1} x_{2} \mathrm{Ox}_{2}
$$

電池反応に伴う Gibbs 自由エネルギー変化は次式で与えら れる。

$$
-\Delta G=n_{1} n_{2} F\left(E_{1}-E_{2}\right)
$$

前述のように $E_{1}-E_{2}$ は電池の起電力である.

等圧下での化学反応に伴う化学エネルギ一変化は, 一部は 熱エネルギー $Q$ として取り出すことができ，また，一部は 熱エネルギーの発生に伴って乱雑さが増加することにより散

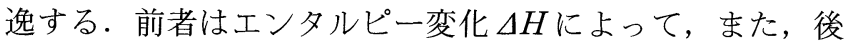
者はエントロピー変化 $\Delta S$ と温度 $T$ との積 $T \Delta S$ によて表 すことができる。

$$
\Delta G=\Delta H-T \Delta S
$$

式(4.9)は, 電池においては化学反応に伴う有効エネルギー のすべてが電気エネルギーに変換されることを表している. 物質の燃焼によって熱エネルギーとして熱機関が取り出すこ とのできるエネルギーは $\Delta H$ であるので, 熱機関の効率と 比較するために, 熱エネルギーベースで電池のエネルギー変 換効率を示すことが行われている.

$$
\varepsilon_{\text {the }}=(-\Delta G /-\Delta H) \times 100 \quad(\%)
$$

$\varepsilon_{\text {the }}$ を電池の理論エネルギー変換効率 (theoretical energy conversion efficiency) という(9).

\section{$4 \cdot 6$ 電池反応の動力学}

\section{$4 \cdot 6 \cdot 1$ 電池反応の分極曲線}

放電および充電に伴う電池の正極および負極の分極状態を 図4·3に模式的に示した．正極および負極の分極曲線は第 2 


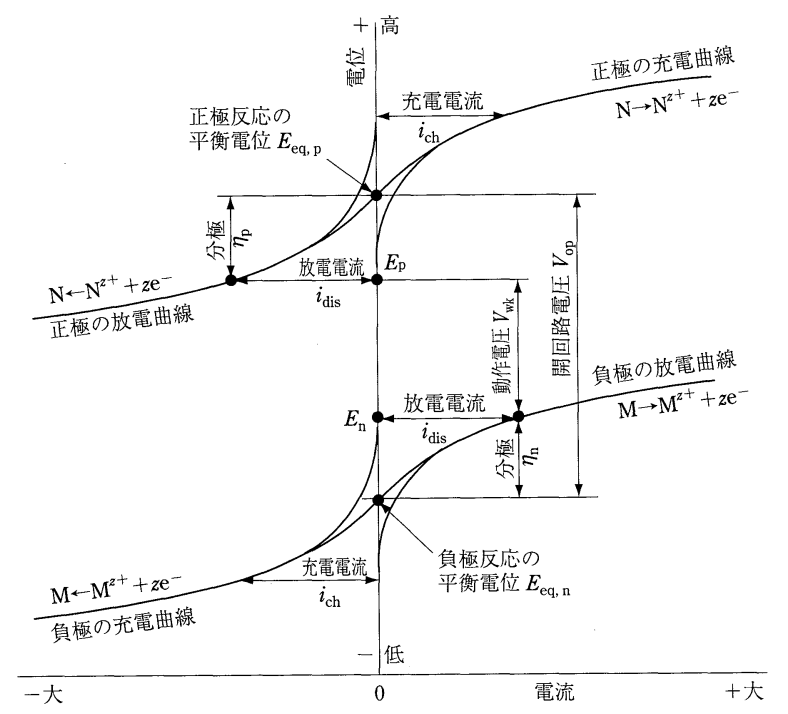

図 $4 \cdot 3$ 放電および充電に伴う正極および負極の分極曲 線の変化.

章2·8で述べた Butler-Volmerの式 $i=i_{0}\{\exp (\alpha z F \eta / R T)-\exp [-(1-\alpha) z F \eta / R T]\} \quad(4 \cdot 12)$ に従うものとする (記号の意味は第 2 章 $2 \cdot 8$ 参照) ${ }^{(10)(11)}$. 回 路状態にある電池では，正極および負極の電位はそれぞれの 平衡電位， $E_{\mathrm{eq}, \mathrm{p}}$ 抢よび $E_{\mathrm{eq}, \mathrm{n}}$ ，に近い電位にある。 $E_{\mathrm{eq}, \mathrm{p}}$ と $E_{\mathrm{eq}, \mathrm{n}}$ の差が開回路電圧 (open circuit voltage) $V_{\mathrm{op}}$ である. 回 路に外部負荷が接続され, 回路が閉じられた状態になると, 電池反応が自発的に進む方向に放電電流 $i_{\mathrm{dis}}$ が流れ，正極抒 よび負極はそれぞれカソードおよびアノード分極する．分極 の大きさ (過電圧に対応)は，それぞれの電極の性質および状 態に依存する．放電電流 $i_{\text {dis }}$ におけるそれぞれの電極の分極 電位 $E_{\mathrm{p}}$ および $E_{\mathrm{n}}$ の差が動作電圧 (working voltage) $V_{\mathrm{wk}}$ と なる。したがって，分極が小さい方が，大きな放電電流にお いても大きな動作電圧が得られることになる.

充電は, 充電電流 $i_{\mathrm{ch}}$ で行われる. 図4·3に見るように, 充電中の電圧は開回路電圧よりも大きくなる.

正極および負極のアノードおよびカソード分極曲線の可逆 性が良い(二次電池に相当) ときには, 放電電流 $i_{\mathrm{dis}}$ と同じ大 きさの充電電流を放電時間 $t_{\mathrm{dis}}$ と同じ時間流せば，すなわ ち, 放電電気量 $Q_{\text {dis }}$ とおなじ充電電気量 $Q_{\mathrm{ch}}$ を流せば, 正極 および負極は元の状態に回復することになる. しかし，可逆 性が悪い(一次電池に相当) ときには, 放電電流と同じ充電電 流を放電時間と同じ時間流しても, 元の状態には戻らない.

\section{$4 \cdot 6 \cdot 2$ 過充電, 過放電と分極曲線}

電池を過放電あるいは過充電したときに正極および負極で 起こりうる反応の分極曲線を図4-4に模式的に示した．電池 の放電電流 $i_{\mathrm{dis}}$ が過度に大きすぎると，負極が金属電極の場 合には表面酸化皮膜の形成による不働態化 (passivation)現象 が生じ，放電電流が著しく小さくなる。 また，充電電流 $i_{\mathrm{ch}}$ が過度に大きいときには，正極では溶媒の酸化，負極では溶 媒の還元による溶媒の分解が生ずる. 溶媒が水溶液のときに は, 正極では $\mathrm{O}_{2}$ 発生, 負極では $\mathrm{H}_{2}$ 発生が起こり, 密封型 電池の場合には内圧上昇による電池の破壊につながる．この ように, 過充電 (overcharging), 過放電 (overdischarge) は

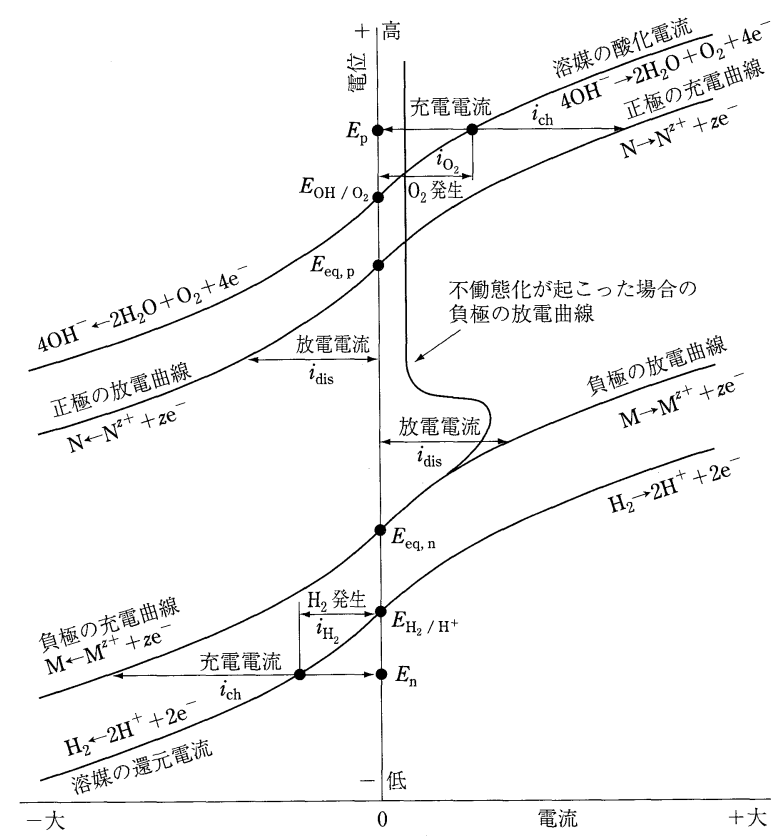

図 4 -4 過放電, 過充電に伴う正極および負極の分極曲 線の変化.

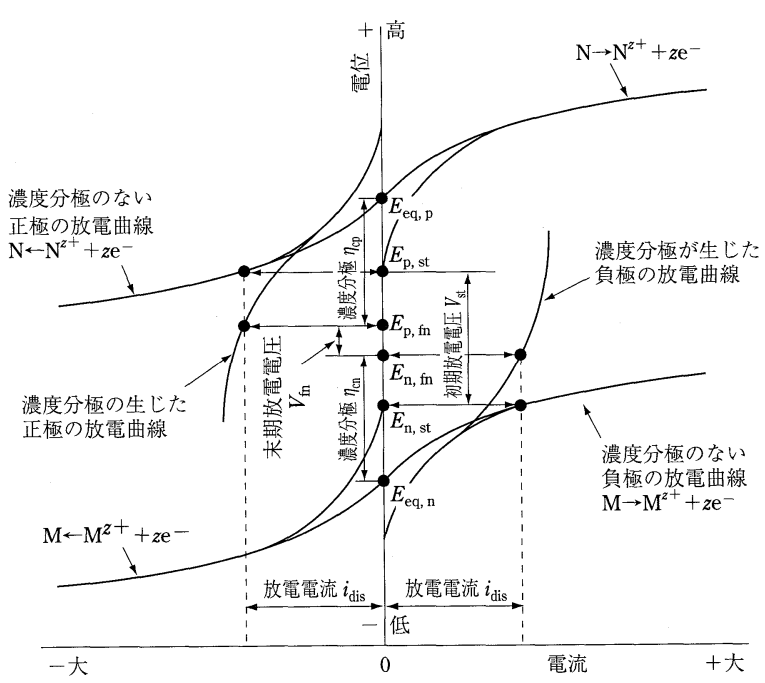

図4.5 放電に伴い濃度分極が生ずる場合の正極および 負極の分極曲線の変化.

電池の性能を著しく低下させる原因となる.

\section{$4 \cdot 6 \cdot 3$ 放電に伴う分極曲線の変化}

放電の経過に伴い濃度分極が生ずる場合の正極および負極 の分極状熊の変化を図4.5に模式的に示した．完全充電され た状態の電池に外部負荷をつなぎ，一定の放電電流 $i_{\text {dis }}$ で放 電を行うと，正極执よび負極とも最初は活性化分極だけを示 すカソードおよびアノード分極曲線に従って電流が流れ, 初 期放電電圧 $V_{\text {st }}$ を示す。しばらく放電を続けると正極および 負極の表面付近には反応生成物が溜まり，電極反応は濃度分 極 $\eta_{\mathrm{cp}}$ および $\eta_{\mathrm{cn}}$ を示すようになる。この段階での電流は， 濃度分極のある分極曲線に従って流れる，濃度分極が大きく なり，電池反応の自発的な進行が困難になると，末期放電電 圧 $V_{\mathrm{fn}}$ を示す，このように，電池の動作電圧は $V_{\mathrm{st}}$ から $V_{\mathrm{fn}}$ まで，放電に伴って低下する. 


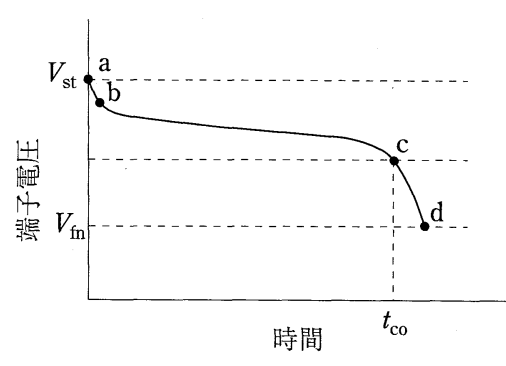

図 4 -6 電池の放電曲線.

定電流充電をする場合にはこの逆過程が起こり，充電中の 電圧は $V_{\mathrm{fn}}$ から $V_{\mathrm{st}}$ まで回復する.

\section{$4 \cdot 6 \cdot 4$ 電池の放電曲線}

完全充電された電池に外部負荷を繋ぎ一定電流で放電を行 うと，多くの場合，図4.60ような放電曲線が得られる.

$\mathrm{a}-\mathrm{b}$ 間の初期降下部分は，活性化分極と電池の内部抵抗に よる電圧降下である. その後, 濃度分極の増大に伴い端子電 圧は b から d まで低下する. $\mathrm{d}$ まで放電すると正極および負 極活物質に不可逆的な変化が生ずる恐れがある，そのため， 二次電池では，初期放電電圧の値の $10 \%$ 位の值まで電圧が 低下したcのところで放電を打ち切る，cの位置を放電終止 電圧 (cut-off voltage) という. c に達するまでの放電時間 $t_{\mathrm{co}}$ と放電電流 $i_{\mathrm{dis}}$ の積 $\left(t_{\mathrm{co}} \times i_{\mathrm{dis}}\right)$ が電池の容量である. $\mathrm{b}-\mathrm{c}$ 間が 長くかつ安定している電池ほど性能が良い。

充電の場合には， $\mathrm{c} \rightarrow \mathrm{b} \rightarrow \mathrm{a}$ と逆の過程をたどるのが普通で ある、しかし，充放電サイクルを繰り返すと，充電しても $V_{\text {st }}$ の值まで端子電圧が回復しなくなる，これは，充放電に 伴って徐々に正極および負極活物質に不可逆な変化を生じた ためである。

\section{$4 \cdot 7$ 電池性能の指標}

電池の性能を相互に比較するためには，客観的な性能の表 示法が必要である.ここでは, 電池の性能の表示に使われて いる幾つかの術語の内容について説明すると共に電池の性能 を高めるにはどのようにすれば良いかその考え方について解 説する ${ }^{(12)(13)}$.

理論容量(theoretical capacity)：電池活物質が全て消費さ れるとして, Faradayの法則から計算される電気量 $Q(\mathrm{C}$, $\mathrm{A} \cdot \mathrm{s})$ のこと.

$$
C_{\text {the }}=m n F / M=m /(M / n F)
$$

ここで， $C_{\text {the }}$ は理論容量， $m$ は電池活物質の質量 $(\mathrm{g}), F$ は Faraday 定数 $(96485 \mathrm{C} / \mathrm{mol}), M$ は電池活物質のモル質量 ( $\mathrm{g} / \mathrm{mol}), n$ は反応に関与する電子数. 電池の理論容量を大 きくするためには, 電気化学当量 $(M / n F)$ を小さくする必要 がある。すなわち，モル質量が小さく反応に関与する電子数 の多い活物質を選ぶ必要がある.

容量 (capacity)：電池を放電させたとき，端子電圧が放電 終止電圧に達するまでに取り出された電気量 $(\mathrm{Ah}$ または $\mathrm{mAh})$ のこと.すなわち

$$
C_{\text {cell }}=t_{\text {co }} \times i_{\text {dis }}
$$

ここで, $C_{\text {cell }}$ は電池, の容量. 電池活物質を全部放電させる訳 でないので，理論容量よりは小さくなる，温度，放電電流お
よび終止電圧を規定して, 完全充電した電池から取り出せる 基準的な電気量を定格容量 (rated capacity) という. 定格容 量に対する放電電気量の比率 $(\%)$ を放電深さ (depth of discharge; DOD) という.

理論エネルギー密度 (theoretical energy density) : 電池活 物質がすべて消費されるとして電池から取り出されるエネル ギーで,

$$
G_{\text {the }}=E_{\text {cell }} \times C_{\text {the }}
$$

として求められる。ここで, $G_{\text {the }}$ は理論エネルギ一密度,

$E_{\text {cell }}$ は電池の起電力. 単位質量当たりで表示した值 $(\mathrm{kJ} / \mathrm{kg})$ と単位体積当たりで表示した值 $\left(\mathrm{kJ} / \mathrm{m}^{3}\right)$ がある.これらの值 が大きい活物質を選べば，小型軽量で大エネルギー密度の電 池が得られる。

エネルギー密度 (energy density)：実際に電池を使用した とき, 電池の単位質量当たりあるいは単位体積当たり取り出 すことのできるエネルギーで,

$$
\begin{aligned}
G_{\text {cell }} & =V_{\text {dis }} \times i_{\text {dis }} \times t_{\text {co }} \\
& =V_{\text {dis }} \times C_{\text {cell }}
\end{aligned}
$$

で求めることができる. 質量エネルギー密度 (specific energy: Wh/kg) と体積エネルギー密度 (energy density: $\mathrm{kJ} /$ $\left.\mathrm{m}^{3}\right)$ がある。

出力密度 (power density)：電池の単位質量あるいは単位 体積当たり取り出すことができる出力で,

$$
P_{\mathrm{pd}}=V_{\text {dis }} \times i_{\text {max }}
$$

で求められる.ここで， $P_{\mathrm{pd}}$ は出力密度， $i_{\max }$ は許容最大電 流. 質量出力密度 (specific power: $W / \mathrm{kg}$ ) または体積出力密 度 (power density: $\mathrm{W} / \mathrm{m}^{3}$ ) で表される.

自己放電 (self discharge)：電池の貯蔵中に電池活物質が 電解液と反応して消費され, 電池の容量が低下すること. 自 己放電を少なくするためには, 活物質と電解液が自発的に反 応しないようにする必要がある。

サイクル寿命 (cycle life)：電池の充放電を繰り返したと き, 定格容量の何\%かの数值まで容量が低下する間に何回繰 り返し充放電ができるかを表す数. 充放電の条件抢よび試験 温度によって変わる. サイクル寿命を長くするためには, 放 電後充電によって活物質が完全に元の状態に戻るようにする 必要がある。

$\mathbf{n C}$ 放電 : 定格容量 $C$ を持った電池を $(1 / n)$ 時間で使い尽 くす電流值で放電すること.

\section{$4 \cdot 8$ 実用電池に求められる条件}

Gibbs 自由エネルギーの減少を伴う化学反応はすべて電池 反応として利用できるので, 電池の種類は無限に近く存在す ることになるが，実用に供されている電池の種類は比較的限 られている，それは，実用電池には次のような条件が求めら れているからである。

(1)エネルギ一密度が高いこと，(2)出力密度が高いこと，(3) 容量が大きいこと，(4)サイクル寿命が長いこと，(5)自己放電 率が小さいこと, (6)急速充電が可能なこと, (7)充電効率が高 いこと，(8)動作温度範囲が広いこと，(9)残存容量表示が可能 なこと，(10)メンテナンスフリーであること，(11)有害物質を含 まないこと，(12)リサイクルが可能であること，(13)化学反応が 暴走しないこと. 
(1)から(8)までの項目は, 電池の基本性能として求められる 事柄である. (9)，(10)は保守管理上求められる事柄である. (11) から(13)は環境污染を防止し, 安全に使用するために求められ る事柄である。

\section{9 代表的実用電池の電池反応}

表4·1〜 4·3に示したように, 多種多様な一次電池, 二次電 池, 燃料電池が実用に供されている．ここでは実用電池につ いての基本的知識を得るために，世の中で広く用いられてい る代表的な電池について, 電池反応を解説する(3)(4)(9)(14). これらに関しては既に多くの参考書があるので, ごく簡単な 記述に止める. 最近積極的に開発が行われている高性能電池 については，次節において詳述することにする.

\subsection{1 アルカリマンガン乾電池}

概要 : 現在最も使用量の多い一次電池はマンガン乾電池で あるが，マンガン乾電池の電解液 $\left(\mathrm{ZnCl}_{2}\right)$ を高濃度 $\mathrm{KOH}$ に 替えたアルカリマンガン乾電池 (alkaline manganese dioxide-zinc dry cell)(9)(15)は, 容量およびエネルギー密度が マンガン乾電池よりも大きいことから，マンガン乾電池にと って代わりつつある. そのためここではアルカリマンガン乾 電池の電池反応について述べる.

構造 : アルカリマンガン乾電池の正極には電解二酸化マン ガン $\left(\gamma-\mathrm{MnO}_{2}\right)$ と黒鉛の合剂，負極には带鉛 $(\mathrm{Zn})$ 粉末と電解 液とゲル化剂を混ぜてゲル状にしたもの，電解液には $40 \%$ $\mathrm{KOH}$ に酸化亜鉛 $(\mathrm{ZnO})$ を飽和するまで溶解させたものが使 用されている。Znを粉末にしているのは, 電解液に触れる 面積を増すためである。 また, 電解液に $\mathrm{ZnO}$ を飽和させて いるのは，Znの腐食による $\mathrm{H}_{2}$ の発生を防止するためであ る.セパレータにはポリエチレン多孔膜などが用いられる.

電池反応 : アルカリマンガン乾電池の電池反応は, 以下の ように表わされる。

$$
\begin{array}{cc}
\text { 負極 } & \mathrm{Zn}+4 \mathrm{OH}^{-} \longrightarrow \mathrm{Zn}(\mathrm{OH})_{4}^{2-}+2 \mathrm{e}^{-} \\
& \downarrow \\
\text { 放電が進むと } & \mathrm{Zn}(\mathrm{OH})_{4}^{2-} \longrightarrow \mathrm{ZnO}+\mathrm{H}_{2} \mathrm{O}+2 \mathrm{OH}^{-}
\end{array}
$$

$$
+) \text { 正極 }: 2 \mathrm{MnO}_{2}+2 \mathrm{H}_{2} \mathrm{O}+2 \mathrm{e}^{-} \longrightarrow 2 \mathrm{MnOOH}+2 \mathrm{OH}^{-}
$$

全反応 $: \mathrm{Zn}+2 \mathrm{MnO}_{2}+\mathrm{H}_{2} \mathrm{O} \longrightarrow \mathrm{ZnO}+2 \mathrm{MnOOH} \quad(4 \cdot 22)$

全反応式 $(4 \cdot 22)$ から分かるように, 放電の進行と共に電 解液中の $\mathrm{H}_{2} \mathrm{O}$ が消費される. また, 放電が進むと $\mathrm{ZnO}$ の析 出が起こる. 電解液に導電率の大きい高濃度 $\mathrm{KOH}$ を用いて いるため電池の内部抵抗が小さく, 大電流の放電に有利であ り，負荷の大きい条件で使用することができる.

\section{$4 \cdot 9 \cdot 2$ 鉛蓄電池}

概要 : 鉛蓄電池 (lead-acid battery, lead storage battery) (16)(17)は, 自動車用バッテリーを中心に今日最も広く使 われている代表的な二次電池である. その理由は, 技術の成 熟により信頼性が高いこと, 経済性が良いこと, リサイクル 性が良いこと，密閉化がなされメンテナンス性が良いこと，

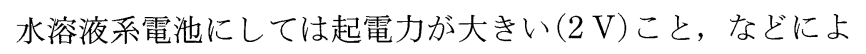
る.
構造 : 正極活物質は二酸化鉛 $\left(\mathrm{PbO}_{2}\right)$, 負極活物質は金属 鉛 $(\mathrm{Pb})$, 電解液は希硫酸 $\left(\mathrm{H}_{2} \mathrm{SO}_{4}\right)$ である. 自動車用の鉛蓄 電池の電極は, ペースト式という方式で作られている.この 方式の正極は, 鉛粉末 (一酸化鉛と金属鉛の混合物) と異方性 黒鉛粉 (導電剂) と $\mathrm{H}_{2} \mathrm{SO}_{4}$ の練膏物を $\mathrm{Pb}-1.5 \sim 3.0 \% \mathrm{Sb}-0.1$ $\sim 0.5 \% \mathrm{As}$ 合金の格子状極板に充填し，この極板を $\mathrm{H}_{2} \mathrm{SO}_{4}$ 中で化成 (電解酸化) して鉛粉末を $\mathrm{PbO}_{2}$ に変えたものであ る.負極は鉛粉末と防縮剤(硫酸バリウムやリグニン系化合 物 ; 粒子の凝集を防止) と $\mathrm{H}_{2} \mathrm{SO}_{4}$ の練膏物を $\mathrm{Pb}-0.5 \sim 1.0 \%$ $\mathrm{Ca}-0.3 \sim 1.5 \% \mathrm{Sn}$ 合金の格子状極板に充填し，これを $\mathrm{H}_{2} \mathrm{SO}_{4}$ 中で化成 (電解還元) して鉛粉末を $\mathrm{Pb}$ に変えたものである. 電解液には, 自動車用の場合, 比重 $1.280(293 \mathrm{~K})$ の $\mathrm{H}_{2} \mathrm{SO}_{4}$ が使われている. セパレータには, 親水性ポリエチレン繊維 と多孔質シリカ粉末から成る抄紙セパレータ(ガラス繊維マ ットと併用)などが用いられている. シリカ粉末やガラス繊 維マットは, 電解液の保持体として働く。

電池反応 : 鉛蓄電池の電池反応は, 以下のように表される.

$$
\begin{aligned}
& \text { 負極 }: \mathrm{Pb}+\mathrm{SO}_{4}^{2-} \underset{\text { 充䉓 }}{\stackrel{\text { 放電 }}{\rightleftarrows}} \mathrm{PbSO}_{4}+2 \mathrm{e}^{-} \\
& +) \text {正極 }: \mathrm{PbO}_{2}+4 \mathrm{H}^{+}+\mathrm{SO}_{4}^{2-}+2 \mathrm{e}^{-} \underset{\text { 充電 }}{\stackrel{\text { 故電 }}{\longrightarrow}} \mathrm{PbSO}_{4}+2 \mathrm{H}_{2} \mathrm{O} \\
& \text { 全反応 : } \mathrm{PbO}_{2}+\mathrm{Pb}+2 \mathrm{H}_{2} \mathrm{SO}_{4} \underset{\text { 充電 }}{\stackrel{\text { 放電 }}{\rightleftarrows}} 2 \mathrm{PbSO}_{4}+2 \mathrm{H}_{2} \mathrm{O} \quad(4 \cdot 25)
\end{aligned}
$$
式(4·25)に見るごとく, 放電によって $\mathrm{H}_{2} \mathrm{SO}_{4}$ が消費され, $\mathrm{H}_{2} \mathrm{O}$ ができる. すなわち, $\mathrm{H}_{2} \mathrm{SO}_{4}$ 溶液の濃度が減少し比重 が低下する. 充電すると $\mathrm{H}_{2} \mathrm{SO}_{4}$ が生成し, $\mathrm{H}_{2} \mathrm{SO}_{4}$ 溶液の濃 度が増し比重が大きくなる。このように, $\mathrm{H}_{2} \mathrm{SO}_{4}$ は電池反 応に関与しており, 電解質としての働きばかりではなく, 活 物質としての働きもある.

\section{$4 \cdot 9 \cdot 3$ リン酸型燃料電池}

概要 : 各種然料電池の中でリン酸型然料電池 (phosphoric acid fuel cell; PAFC) (18)(19) は電気事業用执よ゙自家用電源と して一番実用化が進んでいる. 電池の出力性能は $2.5 \mathrm{kA} /$ $\mathrm{m}^{2}, 0.65 \sim 0.7 \mathrm{~V} /$ 単セル, 出力密度 $1.7 \mathrm{~kW} / \mathrm{m}^{2}$ である. 単 セルを積層したスタック (stack)の形で用いられる.この電 池の利点は, 電熱併給 (コシェネレーション; cogeneration) によって電池システムの総合エネルギー効率 (元の燃料の燃 焼エネルギーに対する変換電力と利用熱エネルギーの総和の 割合)を高く $(>70 \%)$ することができることである.

構造：負極には白金触媒を付けた多孔質カーボン紙が，そ して，正極には白金合金 (Pt-Cr, Pt-Vなど) 触媒を付けた多 孔質力ーボン紙が用いられる，セパレータには，炭素を樹脂 で固めたガス流路付きカーボン樹脂板が用いられている. 電 解質としては, 多孔質の炭化珪素 $(\mathrm{SiC})$ 板に含浸させた濃度 約 $100 \%$ のリン酸 $\left(\mathrm{H}_{3} \mathrm{PO}_{4}\right)(105 \%$ ポリリン酸)が用いられ る. 燃料ガスは $\mathrm{H}_{2}$ であるが，水素ガス源として都市ガス （天然ガス）などを改質した $\mathrm{H}_{2}$ を主成分とする改質ガスが用 いられている. 酸化剂の酸素ガス源には, 空気が用いられる.

電池反応：この電池の電池反応は以下のように表される.

負極 : $\mathrm{H}_{2} \longrightarrow 2 \mathrm{H}^{+}+2 \mathrm{e}^{-}$

+ ) 正極 : $1 / 2 \mathrm{O}_{2}+2 \mathrm{H}^{+}+2 \mathrm{e}^{-} \longrightarrow \mathrm{H}_{2} \mathrm{O}$

全反応 : $\mathrm{H}_{2}+1 / 2 \mathrm{O}_{2} \rightarrow \mathrm{H}_{2} \mathrm{O}$ 
正極抢よび負極での反応には，三つの異なる相に存在する物 質が同時に関与している．例えば，負極では次のようになっ ている.

$$
\left.\mathrm{H}_{2}(\text { 燃料ガス }) \longrightarrow 2 \mathrm{H}^{+}(\text {電解質水溶液 })+2 \mathrm{e}^{-} \text {(電極 }\right)
$$

このような電気化学反応は三相界面 (three phase zone)で行 われるので，反応速度を增すためには三相界面をできるだけ 増やす必要がある.三相界面は触媒と燃料ガスと電解質水溶 液によって形成される．したがって，反応速度を増すには触 媒の担持量も増やす必要がある。電池は，正負両電極上での 反応の過電圧を下げるためと白金触媒の一酸化炭素 $(\mathrm{CO})$ に よる被毒を避けるために， $473 \mathrm{~K} て ゙$ 運転されている.

\section{$4 \cdot 10$ 最近の高性能電池の電池反応}

最近では，大容量でかつエネルギー密度の高い高性能一次 電池, 二次電池が携帯電子機器用電源として利用されてい る. また, 小型軽量で発電効率の高い燃料電池が電気自動車 用電源として積極的に開発されつつある.ここでは, 最新の 電池技術の一端を理解するために，代表的な高性能一次電 池, 二次電池, 燃料電池について, それらの原理と材料を解 説する.

\section{$4 \cdot 10 \cdot 1$ 二酸化マンガンリチウム乾電池}

概要 : 二酸化マンガンリチウム乾電池 (manganese dioxide-lithium cell) ${ }^{(20)}$ は, 端子電圧が高く $(3 \mathrm{~V})$, エネルギ 一密度が大きく, 放電曲線が平坦で, 自己放電が少なく, 温 度特性が良い $(223 \sim 353 \mathrm{~K})$ 優れた一次電池である。 そのた め, カメラ, 腕時計, 電卓などの小型精密機器の電源として 広い用途がある.ただし，端子電圧が高いため，電池の両極 間の表面が水分を帯びると, 水を分解して自己放電しやすい ので注意する必要がある。

構造 : この電池は, 正極活物質に無水二酸化マンガン $(\gamma$ 抢よび $\left.\beta-\mathrm{MnO}_{2}\right)$, 負極活物質に金属リチウム $(\mathrm{Li})$, 電解液 にプロピレンカーボネート (PC) と 1,2-ジメトキシエタン (DME)の混合溶媒に過塩素酸リチウム $\left(\mathrm{LiClO}_{4}\right)$ を溶解した ものを用いている．セパレータには，高分子不織布と高分子 微多孔膜から成る二層膜などが用いられる。電解液はセパレ 一タ中に保持されることが多い，電池の単セルの構成を図 4.7に示す.

電池反応：正極に用いる $\gamma$ および $\beta-\mathrm{MnO}_{2}$ は層間化合物 であり,これらの結晶構造のチャンネル状の空隙には Li の ような小さな原子が出入りすることができる[入ることをイ ンターカレーション(intercalation), 出ることをデインター カレーション(deintercalation) という]. 電解液中の $\mathrm{Li}^{+}$イ オンが $\mathrm{MnO}_{2}$ とインターカレーション反応を起こすと, $\mathrm{MnO}_{2}$ 結晶格子中の $\mathrm{Mn}^{4+}$ イオンの一部は $\mathrm{Mn}^{3+}$ に還元され る.この電池では, インターカレーション反応を電池反応に 利用している.

負極 : $\mathrm{Li} \longrightarrow \mathrm{Li}^{+}+\mathrm{e}^{-}$

+)正極 : $\mathrm{Mn}(\mathbb{V}) \mathrm{O}_{2}+\mathrm{Li}^{+}+\mathrm{e}^{-} \rightarrow \mathrm{Mn}($ III $) \mathrm{O}_{2}\left(\mathrm{Li}^{+}\right)(4 \cdot 31)$

全反応 $: \mathrm{Li}+\mathrm{Mn}(\mathbb{N}) \mathrm{O}_{2} \longrightarrow \mathrm{Mn}(\mathbb{I I I}) \mathrm{O}_{2}\left(\mathrm{Li}^{+}\right) \quad$ (4.32)

ただし， $\mathrm{Mn}(\mathrm{N}) \mathrm{O}_{2}$ は $\mathrm{Mn}^{4+}$ から成る $\mathrm{MnO}_{2}, \mathrm{Mn}(\mathrm{III}) \mathrm{O}_{2}$ $\left(\mathrm{Li}^{+}\right)$は $\mathrm{Li}^{+}$が入り一部の $\mathrm{Mn}^{4+}$ が $\mathrm{Mn}^{3+}$ と成った $\mathrm{MnO}_{2}$ を

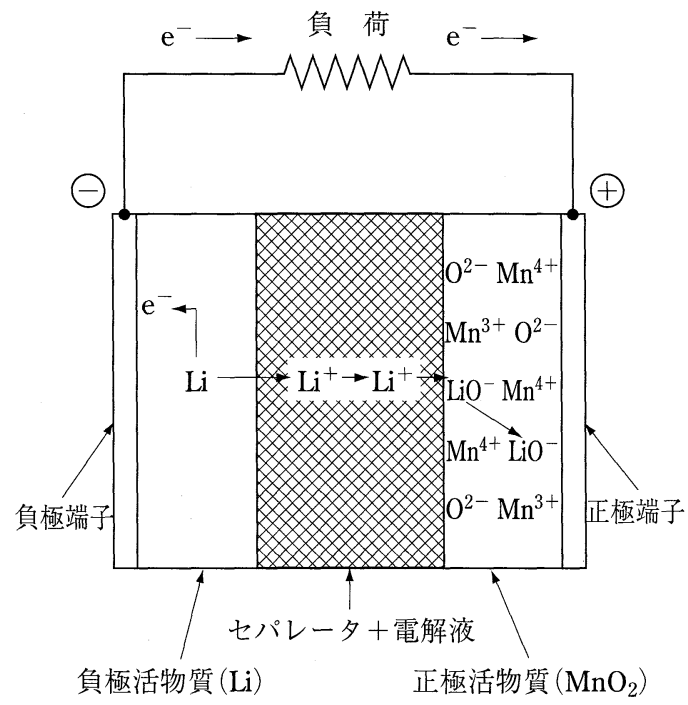

図4.7 二酸化マンガンリチウム乾電池の単セルの構成.

指している。

\section{4·10.2 リチウムイオン二次電池}

概要：リチウムイオン二次電池 (lithium ion battery) (21)-(25) は, エネルギー密度が非常に大きい, 単セル当 たりの電圧が高い $(3.6 \mathrm{~V})$, 出力密度が大きい, サイクル寿 命が良い, 使用温度範囲が広い, 急速充電が可能, 充放電効 率が高い, 自己放電率が低い, 残存容量表示が容易, メモリ 一効果が無い，などの優れた長所を持つために，携带電子機 器用の小型電源として広く用いられている. また, 電気自動 車用のコンパクトな電源としても開発が進められている.た だし, 短所として, 可燃性の有機溶媒を含むため安全への対 策が必要，正極活物質のコストが高い，過充放電に弱いので 充放電制御回路が必要，なぞがあり，これらには十分配慮し なければならない。

構造：負極活物質にリチウム・炭素層間化合物 (lithiumcarbon intercalation compound) $\mathrm{Li}_{x} \mathrm{C}_{6}$ が，そして, 正極活物 質に $\mathrm{LiCoO}_{2}, \mathrm{LiNiO}_{2}, \mathrm{LiMn}_{2} \mathrm{O}_{4}$ などのリチウム複酸化物が 用いられている.これらの複酸化物も層状構造かあるいはチ ヤンネル構造をしており, 放電抢よび充電に伴って層間ある いはチャンネル内に $\mathrm{Li}^{+}$イオンがインターカレーションお よびデインターカレーションされる. 電解液には, プロピレ ンカーボネート (PC) とジエチルカーボネート (DEC)の混合 溶媒などに六フッ化リン酸リチウム $\left(\mathrm{LiPF}_{6}\right)$ を溶解させた有 機非水溶液が用いられている. セパレータには, ポリエチレ ンやポリプロピレン製の微細多孔膜が用いられている。これ らの膜にはシャットダウン機能があり, 短絡などによって電 池温度が異常上昇 (393 K 位まで)すると膜が熱収縮して孔を 閉じ，イオンの通路が遮断される。これによって過大電流に よる電池の発火や破裂などの事故を防止することができる.

この電池の単セル構成を図4-8に示した。

その他, さらなる安全対策として, 電池にはPTC 素子 (温度が上昇すると電流を遮断), 保護回路 (過充放電のとき 外部回路を切断), 電流遮断機構(内圧上昇のとき放電回路を 遮断), 安全并(内圧上昇のときガスを放出)などが付けられ ている. 
電池反応 : この電池の電池反応を式 $(4 \cdot 33) \sim(4 \cdot 35)$ に示 す.

負極 $: \mathrm{Li}_{x} \mathrm{C}_{6} \underset{\text { 充電 }}{\stackrel{\text { 放電 }}{\rightleftarrows}} \mathrm{C}_{6}+x \mathrm{Li}^{+}+x \mathrm{e}^{-}$

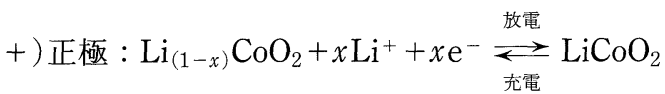

全反応 : $\mathrm{Li}_{(1-x)} \mathrm{CoO}_{2}+\mathrm{Li}_{x} \mathrm{C}_{6} \underset{\text { 放電 }}{\rightleftarrows} \mathrm{LiCoO}_{2}+\mathrm{C}_{6}$

放電時には，負極では $\mathrm{Li}_{x} \mathrm{C}_{6}$ の層間にインターカレーション されていた $\mathrm{Li}^{+}$イオンがデインターカレーションし, 電解 液中に入る. $\mathrm{Li}^{+}$イオンがデインターカレーションしたため $\mathrm{Li}_{x} \mathrm{C}_{6}$ 中で過剰になった電子は導線抢よび負荷を通って正極 に移行する. 正極では, 電解液中の $\mathrm{Li}^{+}$イオンが $\mathrm{LiCoO}_{2}$ の 層間に母構造を変えることなくインターカレーションされ る.インターカレーションした $\mathrm{Li}^{+}$イオンはそのまま $\mathrm{Li}^{+}$ イオンとして存在するため, 正極では正電荷が過剰となる.

この過剰正電荷を補償するため, 負極で過剰となった電子が 正極中に供給される.上記の一連の反応の Gibbs 自由工ネ ルギー変化は大きな負の值であるので, 放電反応は自発的に 進行する. 充電に扔いては, 負極に電子が注入される方向に 電流を流すと，上記とは逆向きの反応が進行する．すなわ ち, 正極においては $\mathrm{LiCoO}_{2}$ から $\mathrm{Li}^{+}$イオンがデインターカ レーションし, 負極では $\mathrm{Li}_{x} \mathrm{C}_{6}$ に $\mathrm{Li}^{+}$イオンがインターカレ 一ションされる.

全反応式 $(4 \cdot 35)$ に見るごとく, 電池反応に電解質や溶媒 はまったく関与していない. 充電・放電に伴って, $\mathrm{Li}^{+}$イオ ンが正極活物質と負極活物質の層間を行き来するだけであ る.このような充放電機構を有する電池をロッキング・チェ ア型電池あるいはスウィング型電池と呼んでいる.

\section{$4 \cdot 10 \cdot 3$ 固体高分子型燃料電池}

概要 : 固体高分子型燃料電池 (polymer electrolyte fuel cell; PEFC) (26)-(28) は電解質として厚さ $<50 \mu \mathrm{m}$ の固体高分 子薄膜を使用している. そのため, 電池全体を小型軽量にす ることができる. 電池の出力性能は $10 \sim 30 \mathrm{kA} / \mathrm{m}^{2}, 0.6$ $0.7 \mathrm{~V} /$ 単セル, 出力密度 $6 \sim 21 \mathrm{~kW} / \mathrm{m}^{2}$ である. このよう に, 運転電流密度や出力密度が大きく, 小型軽量で, 起動・ 停止時間が短い，などの特長がある．このような特長は移動 体用電源に適していることから，かつてはシェミ二宇宙船に 搭載された実績があり，また最近では電気自動車用の車載電

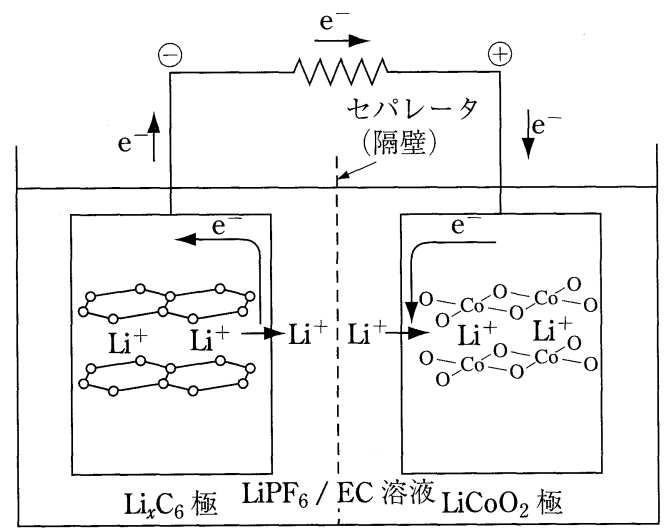

図4.8 リチウムイオン二次電池の単セルの構成.
源として活発な開発が行われている.

構造 : この型の電池では, 電解質にプロトン $\left(\mathrm{H}^{+}\right)$伝導体 である固体高分子膜が使用される，そのため，プロトン交換 膜型燃料電池 (proton exchange membrane fuel cell; PEMFC) とも呼ばれる. よく使用されるのはペルフルオロ スルホン酸 (perfluorosulfonic acid)膜で, デュポン社のナフ イオン (Nafion, 商品名)が有名である. 燃料ガスには都市ガ スの改質ガス中の $\mathrm{H}_{2}$ が，酸化剂には空気中の $\mathrm{O}_{2}$ が用いら れる。負極は，固体高分子膜の片面に白金合金 $\left(\mathrm{Pt}_{35} \mathrm{Ru}_{65}\right)$ 触 媒を担持したカーボンブラックを粘着剤のフッ素樹脂 (PTFE，テフロン)粉末と共に塗り付け，この上にカーボン 繊維を押し付けて形成する．正極は，固体高分子膜の反対側 の面に白金触媒を同様にして塗り，カーボン繊維を押し付け て形成する，セパレータは，ガス流路を有するカーボン樹脂 板である.この電池の作動温度は，273～ $343 \mathrm{~K}$ である. 電 池の単セルの構成を図4.9に示した．単セル内の負極・触媒 層 $\mid$ 電解質 $\mid$ 触媒層・正極の部分を膜電極接合体 (membrane electrode assembly; MEA) と呼んでいる. MEAの厚さは約 $100 \mu \mathrm{m}$ である. 電池は単セルを積層したスタックの形で用 いられる.

ペルフルオロスルホン酸膜は図4-10に示すような分子構造

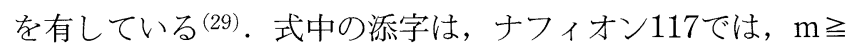
$1, \mathrm{n}=2, \mathrm{x}=5 \sim 13.5, \mathrm{y}=1000$ である. 分子構造は, 疎水性の 主鎖 (ペルフルオロアルキレン基) と親水性の側鎖(末端にス ルホン酸基 $\mathrm{HSO}_{3}^{-}$を付けたペルフルオロビニルエーテル基） からなり，主鎖は分子の骨格を構成し，側鎖は分子内に直径 約 $4 \mathrm{~nm}$ の球状クラスタを多数形成している( ${ }^{(30)}$. クラスタ は $1 \mathrm{~nm}$ 位の間隔で狭いチャンネルで連結されている.クラ スタは側鎖末端のスルホン酸基 $\mathrm{HSO}_{3}^{-}$, これと対になるカ チオン, 抢よびそれらを水和する水分子からなっている. $\mathrm{HSO}_{3}^{-}$と対カチオンはクラスタ内に電気二重層を形成す る.プロトン(正確には hydronium ion; $\mathrm{H}_{3} \mathrm{O}^{+}$) はこのよう

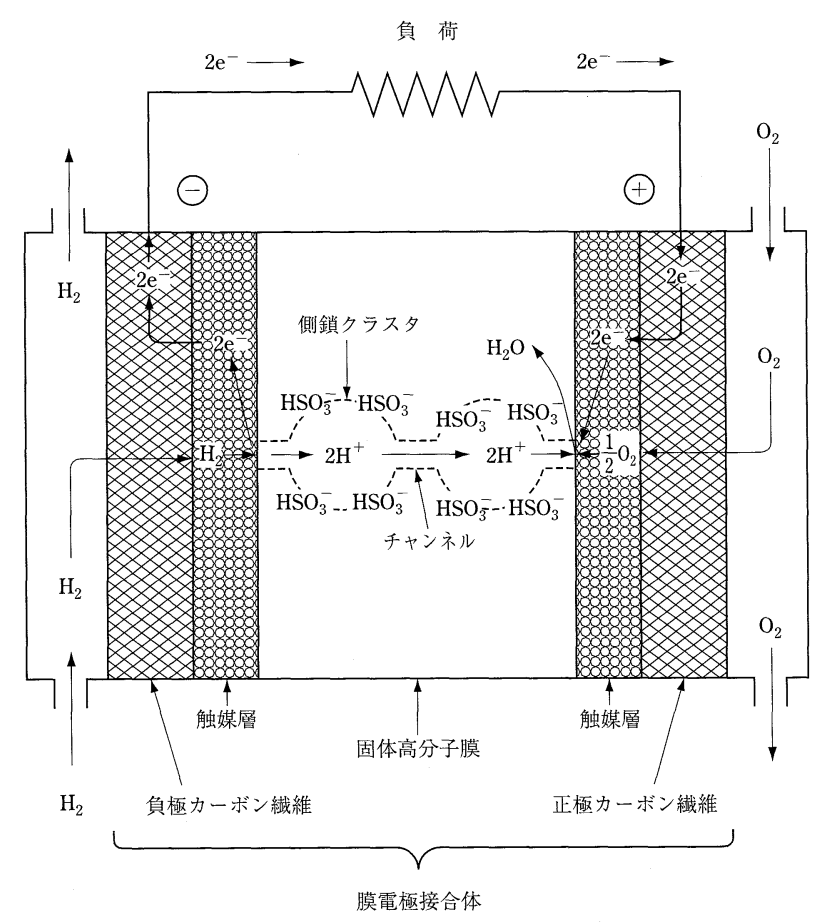

図4.9 固体高分子型然料電池の単セルの構成. 


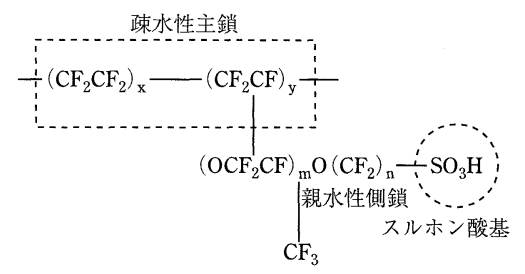

図4·10 ペルフルオロ スルホン酸膜の分子構 造.

な状態のクラスタ内を水溶液中とほとんど同じ機構 [プロト ンジャンプ機構 (proton-jump mechanism) : $\mathrm{H}_{3} \mathrm{O}^{+}$の一つの 水素結合が隣接 $\mathrm{H}_{2} \mathrm{O}$ 分子に移行して新たな $\mathrm{H}_{3} \mathrm{O}^{+}$となるこ とを繰り返す $\mathrm{H}_{3} \mathrm{O}^{+}$の移動]で伝導する. マイナスイオンは 高分子骨格に固定されて動かず，プロトンのみが移動する. $\mathrm{H}_{2} \mathrm{O}$ がプロトン伝導機構に関与しているので, 膜の水分管 理は重要である.

ナフィオン膜は柔軟であるので, 膜の寸法安定性を増すた めに, 膜の材料を PTFE 多孔体シートに染み込ます, 膜中 に PTFE 細繊維を分散させる, などの方法で補強され, 厚 さ 20〜40 $\mu \mathrm{m}$ の薄膜として使用されている.

電池反応 : 電池反応は以下のように表すことができる.

$$
\text { 負極 }: \mathrm{H}_{2} \longrightarrow 2 \mathrm{H}^{+}+2 \mathrm{e}^{-}
$$

$+)$ 正極 : $1 / 2 \mathrm{O}_{2}+2 \mathrm{H}^{+}+2 \mathrm{e}^{-} \longrightarrow \mathrm{H}_{2} \mathrm{O}$

全反応 : $\mathrm{H}_{2}+1 / 2 \mathrm{O}_{2} \longrightarrow \mathrm{H}_{2} \mathrm{O}$

この電池の作動温度は低いので, 式 $(4 \cdot 36)$ および式 (4·37)の反応を促進するためには白金系触媒を使用しなけ ればならない。負極では, 改質ガスに混じる COによる $\mathrm{Pt}$ の被毒 ( $\mathrm{CO}$ が優先吸着して $\mathrm{H}_{2}$ の吸着を妨げること)を低減 するために， $\mathrm{Pt}_{35} \mathrm{Ru}_{65}$ 合金触媒が用いられている，この触媒 を用いても燃料ガス中の CO 濃度は $10 \mathrm{ppm}$ 以下にする必要 がある. 式(4·37)で生成する $\mathrm{H}_{2} \mathrm{O}$ は膜の加湿に使われる.

\section{$4 \cdot 11$ 電極特性の解析·評価}

化学電池の正極, 負極には様々な活物質が用いられ, また 電極構造も複雑である.どのような活物質をどのような電極 構造で用いたらよいかは, 正極, 負極別々に個々の電極特性 を評価しておく必要がある.ここでは電極の反応特性の解析 と評価に良く用いられる技法について解説する.

\section{$4 \cdot 11 \cdot 1$ クロノポテンショメトリー}

電流を規制して電極の電位の時間变化を調べる方法がクロ ノポテンショメトリー(chronopotentiometry)で, 得られる 電位一時間曲線をクロノポテンショグラム (chronopotentiogram) という(31)。これを電池の正極に適用した場合, 定電 流カソード還元のクロノポテンショグラムは放電時の, そし て定電流アノード酸化のそれは充電時の, 正極の特性を示 す. 図4·11に異なる正極活物質について測定した定電流力ソ ード還元のクロノポテンショグラムを模式的に示す．最初に 活物質の還元電位が，次に溶媒の還元電位が現れる. 活物質 の還元時間 $t_{\mathrm{red}}$ とカソード電流 $i_{\mathrm{red}}$ の積が正極の容量にな る. 大きい容量が得られるものが正極活物質として望まし い. 負極についても同様にして評価を行うことができる.

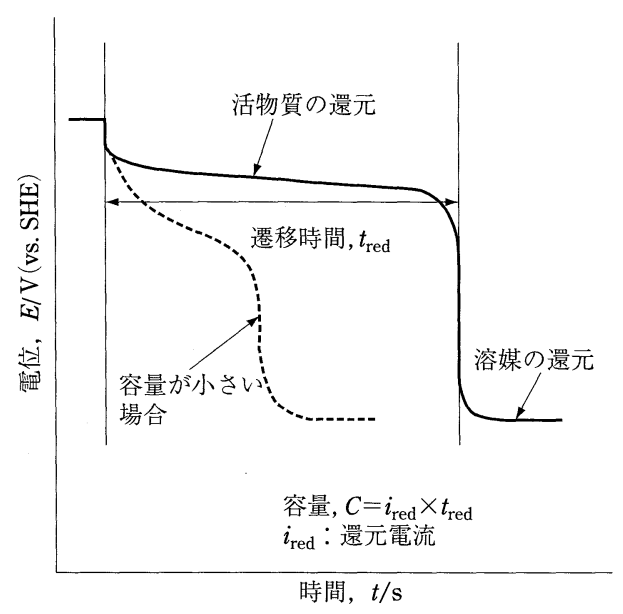

図4·11 正極の定電流カソード還元クロノポテンショ グラム.

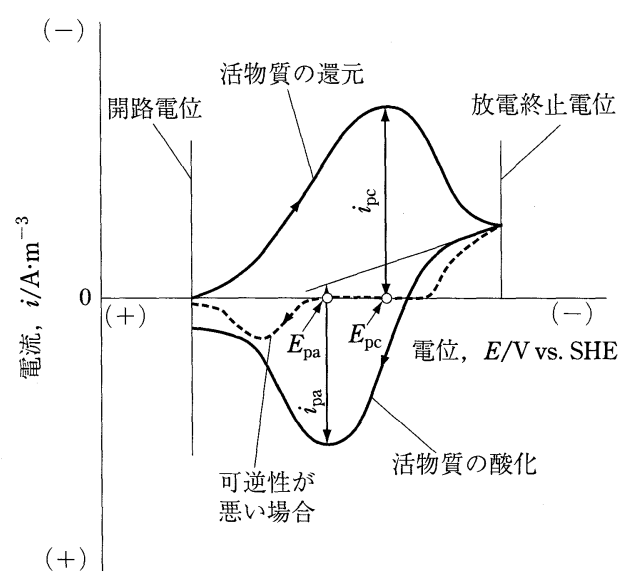

図4.12 正極のサイクリックボルタモグラム. $i_{\mathrm{pc}}$ : カソード電流ピークの電流, $i_{\mathrm{pa}}:$ アノー ド電流ピークの電流, $E_{\mathrm{pc}}$ : カソード電流ピー クの電位, $E_{\mathrm{pa}}$ : アノード電流ピークの電位.

\subsection{1·2 サイクリックボルタンメトリー}

二次電池には反応の可逆性が良い正極, 負極が求められ る. 反応の可逆性の良否は, 充放電条件に対応するある電位 幅でアノードおよびカソード分極曲線を繰り返し測定すれ ば，知ることができる．このような繰り返し分極測定法をサ イクリックボルタンメトリー (cyclic voltammetry), 得られ る一連の分極曲線をサイクリックボルタモグラム (cyclic voltammogram) という(32). 図4·12に正極のサイクリックボル タモグラムを模式的に示した．可逆性の良い電極では, $\left|i_{\mathrm{pa}}\right| /\left|i_{\mathrm{pc}}\right|=1$ であり, また $\Delta E_{\mathrm{p}}=E_{\mathrm{pa}}-E_{\mathrm{pc}}=60 / n(\mathrm{mV})$ と なる ${ }^{(32)}$.ただし， $n$ は反応に関与する電子数である. 可逆 性の悪い電極では, $\left|i_{\mathrm{pa}}\right| /\left|i_{\mathrm{pc}}\right|<1, \Delta E_{\mathrm{p}}>60 / n$ となる. 何回 サイクルを繰り返しても同じサイクリックボルタモグラムを 示すものが好ましい.

\section{$4 \cdot 11 \cdot 3$ 電気化学インピーダンス法}

電池の電極反応としては, 正極, 負極共電子の授受のみが 律速段階となる活性化支配の反応が望ましい. しかし，4.9 および $4 \cdot 10$ 節で見たように，電池には多孔質電極や多孔質 


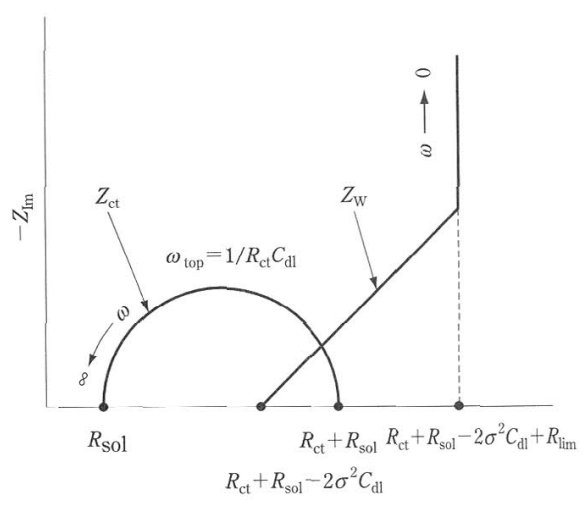

$Z_{\mathrm{Re}}$

図4.13電荷移行過程上拡散過程から成る反応の電気 化学インピーダンス軌跡.

$Z_{\mathrm{ct}}$ : 電荷移行インピーダンス, $Z_{\mathrm{W}}$ : ワールブルグイン ピーダンス, $R_{\mathrm{sol}}$ : 溶液抵抗, $R_{\mathrm{ct}}$ : 電荷移行抵抗, $C_{\mathrm{d} 1}$ : 電気二重層容量, $R_{\lim }$ : 拡散限界抵抗, $\sigma$ : ワールブル グ係数, $\omega$ : 角周波数, $\omega_{\mathrm{top}}$ : 電荷移行インピーダンス 半円の頂点の角周波数.

物質に含浸した電解液が使われており, 反応物, 生成物の拡 散が反応過程に関与する例も多い。したがって, 電池反応に 関与する過程の種類々関与の程度を知ることは重要である. 反応の各素過程は時定数が異なっているので, 広い周波数範 囲で電気化学インピーダンスを測定し，そのベクトル軌跡を ナイキスト図として表示すると各素過程を分離することがで きる。本法については，既に第3 章3·8で紹介してある。電 池電極で見られるインピーダンス軌跡の一例を図4・13に模式 的に示した。この例では, 高周波数側に電荷移行反応による 半円，低周波数側に拡散によるワールブルブインピーダンス を走す斜線と垂直線が見られる。垂直線部分は拡散層に限界 厚さがあることを示している(33). 電荷移行抵抗 $R_{\mathrm{ct}}$ 拈よび 拡散限界抵抗 $R_{\lim }$ が小さいことが望末れる。

\section{文献}

（1）杉本克久：材料電子化学, 日本金属学会, (2003).

(2) 外島 忍, 佐々木英夫: 電気化学 改訂版, 電気学会, (1987), 326.

（3）竹原善一郎：電池一その化学々材料, 大日本図書, (1988), 30.

（4）吉澤四郎監修: 新訂版 新しい電池, 東京電機大学出版局, (1978), 18.

（5）内田 勇：金属表面物性工学, 日本金属学会編, 日本金属学 会, (1990), 274.

（6）王虫佮太：電気化学，東京化学同人，(1967), 105.

（7）田島 栄: 電気化学通論 改訂版, 共立出版, (1969), 111.

（8）喜多英明, 魚崎浩平：電気化学の基礎, 技報堂出版, (1983), 87.

（9）内田 勇, 佐藤祐一: 現代の電気化学, 小沢炤弥監修, 新星 社, (1990), 62 .

(10) K. J. Vetter: Electrochemical Kinetics, Academic Press, (1969), 104.

（11）玉虫佮太 : 電気化学, 東京化学同人, (1967), 211.

(12) 米津邦雄 : 最新実用二次電池, 日本電池株式会社編, 日刊工 業新聞社, (1995), 9.

（13）電気化学協会編：先端電気化学，丸善，(1994), 18.

(14) 逢坂哲彌 : 材料電気化学, 逢坂哲爾, 太田健一郎, 松永 是 共著, 朝倉書店, (1998), 53 .

（15）平井竹次，小梘 勉： Electrochemistory, 59(1991), 732.
（16）米津邦雄：最新実用二次電池, 日本電池株式会社編, 日刊工 業新聞社, (1995), 199.

(17) 坪田正温 : Electrochemistory, 59(1991), 746.

(18) 電気化学協会編 : 先端電気化学, 丸善, (1994), 35.

(19) 岡野一清: Electrochemistory, 58(1990), 886.

(20) 池田宏之助：電池の進化とエレクトロニクス, 工業調査会, (1993), 115.

（21）西 美緒：キーテクノロジー電池，日本化学会監修，(1996), 43.

（22）西 美緒：リチウムイオン二次電池の話, 裳華房, (1997), 33.

（23）芳尾真幸，小沢昭弥編：リチウムイオン二次電池, 日刊工業 新聞社, (1997), 1.

（24）日本化学会編：新型電池の材料化学, 季刊化学総説 No. 49, 2001, 学会出版センター, (2001), 63.

(25) 栗林 功：二次電池の開発と材料, シーエムシー出版, (2002), 44.

（26）電気学会. 燃料電池発電次世代システム技術調査専門委員会 編：燃料電池の技術，オーム社，(2002）, 55 .

(27) 工藤徹一, 山本 治, 岩原弘育: 燃料電池一一熱力学から学ぶ 基礎々開発の実際技術，内田老鶴圃，(2005), 189, 192.

（28）日本化学会編：実力盖成化学スクール 4 一燃料電池, 丸善, (2005), 25, 57, 167.

（29）日本化学会編：新型電池の材料化学, 季刊化学総説 No. 49, 2001, 学会出版センタ一, (2001), 183.

(30) T. D. Gierke, G. E. Mumm and F. C. Wilson: J. Poly. Sci., 19 (1981), 1687.

（31）藤嶋 昭, 相澤益男, 井上 徹: 電気化学測定法 (上), 技報 堂出版, (1984), 173.

(32) 電気化学会編：電気化学測定マニュアル 基礎編, 丸善, (2002), 74 .

(33) 門間聡之, 逢坂哲彌 : Electrochemistory, 62(1994), 676.

\section{演習問題}

鉛蓄電池の起電力は電解液の硫酸の濃度によって変化す る. 起電力と硫酸濃度の関係を示し, 放電, 充電によって起 こる変化を説明せよ。

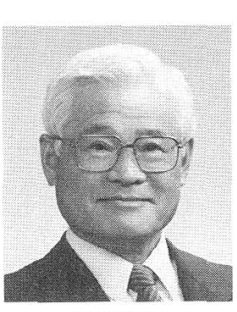

杉本克久

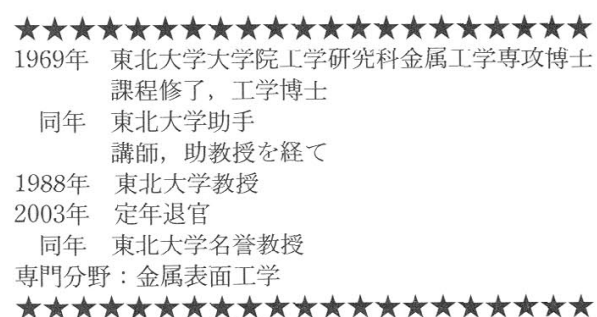

\footnotetext{
一〈解 答〉

鉛蓄電池の正極の反応 $\mathrm{PbO}_{2}+4 \mathrm{H}^{+}+\mathrm{SO}_{4}^{2-}+2 \mathrm{e}^{-} \rightleftarrows$

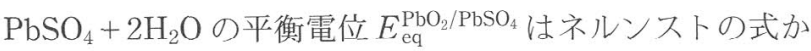

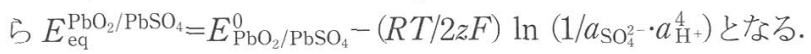
なた，負極の反応は $\mathrm{Pb}+\mathrm{SO}_{4}^{2-} \rightleftarrows \mathrm{PbSO}_{4}+2 \mathrm{e}^{-}$であり，こ れの平衡電位 $E_{\mathrm{eq}}^{\mathrm{PbSO}_{4} / \mathrm{Pb}}$ は $E_{\mathrm{eq}}^{\mathrm{PbSO}_{4} / \mathrm{Pb}}=E_{\mathrm{PbSO}_{4} / \mathrm{Pb}}^{0}-(R T / 2 z F)$ $\ln \left(1 / a_{\mathrm{SO}_{4}^{2-}}\right)$ である。鉛蓄電池の起電力 $E_{\mathrm{emf}}^{\mathrm{Pb} / \mathrm{PbO}_{2}}$ は

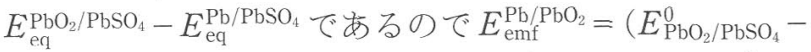
$\left.E_{\mathrm{PbSO}_{4} / \mathrm{Pb}}^{0}\right)-(R T / 2 z F) \ln \left(1 / a_{\mathrm{SO}_{4}^{2-}}^{2-} \cdot a_{\mathrm{H}^{+}}^{4}\right)$ となる. $\mathrm{SO}_{4}^{2-}$ イ オンの活量 $a_{\mathrm{SO}_{4}^{2-}}$ は放電によって小さくなり充電によって 大きくなるので，起電力は放電によって減少し充電によっ

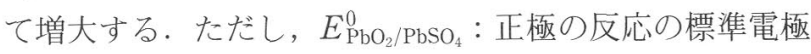
電位, $E_{\mathrm{PbSO}_{4} / \mathrm{Pb}}^{0}$ : 負極の反応の標準電極電位, $a_{\mathrm{H}^{+}}: \mathrm{H}^{+}$イ オンの活量.
} 